\title{
Mu opioid receptor availability in people with psychiatric disorders who died by suicide: a case control study
}

\author{
Elizabeth Scarr ${ }^{1,2^{*}}$, Tammie Terese Money ${ }^{1,2}$, Geoffrey Pavey ${ }^{1}$, Jaclyn Neo ${ }^{1,2}$ and Brian Dean ${ }^{1,2}$
}

\begin{abstract}
Background: Mu opioid receptors have previously been shown to be altered in people with affective disorders who died as a result of suicide. We wished to determine whether these changes were more widespread and independent of psychiatric diagnoses.

Methods: Mu receptor levels were determined using $\left[{ }^{3} \mathrm{H}\right] \mathrm{DAMGO}$ binding in BA24 from 51 control subjects; 38 people with schizophrenia (12 suicides); 20 people with major depressive disorder (15 suicides); 13 people with bipolar disorder ( 5 suicides) and 9 people who had no history of psychiatric disorders but who died as a result of suicide. Mu receptor levels were further determined in BA9 and caudate-putamen from 38 people with schizophrenia and 20 control subjects using $\left.{ }^{3} \mathrm{H}\right] \mathrm{DAMGO}$ binding and, in all three regions, using Western blots. Data was analysed using one-way ANOVAs with Bonferroni's Multiple Comparison Test or, where data either didn't approximate to a binomial distribution or the sample size was too small to determine distribution, a Kruskal-Wallis test with Dunn's Multiple Comparison Test.
\end{abstract}

Results: $\left[{ }^{3} \mathrm{H}\right] \mathrm{DAMGO}$ binding density was lower in people who had died as a result of suicide $(p<0.01)$. People with schizophrenia who had died as a result of suicide had lower binding than control subjects $(p<0.001)$, whilst people with bipolar disorder (non- suicide) had higher levels of binding $(p<0.05)$. $\left[{ }^{3} \mathrm{H}\right] \mathrm{DAMGO}$ binding densities, but not mu protein levels, were significantly decreased in BA9 from people with schizophrenia who died as a result of suicide $(p<0.01)$.

Conclusions: Overall these data suggest that mu opioid receptor availability is decreased in the brains of people with schizophrenia who died as a result of suicide, which would be consistent with increased levels of endogenous ligands occupying these receptors.

\section{Background}

Although the dynamics that contribute to a person dying by suicide are multifactorial, highly complex and vary between individuals [1], studies consistently suggest that psychiatric disorders confer an increased risk of suicide. For example, a Danish study found that nearly $50 \%$ of people who died as a result of suicide either had been or were psychiatric inpatients [2]. A retrospective study in Hong Kong discovered that $80 \%$ of the people who died

\footnotetext{
* Correspondence: elscarr@unimelb.edu.au

${ }^{1}$ Molecular Psychiatry Laboratory, Florey Institute of Neuroscience and Mental Health, Melbourne Brain Centre, University of Melbourne, Parkville VIC 3010, Australia

${ }^{2}$ Department of Psychiatry, Melbourne Brain Centre, The University of Melbourne, Parkville VIC 3010, Australia
}

by suicide had a psychiatric disorder, with $29 \%$ of these having a co-morbid diagnosis [3]. This study also showed the highest risk of suicide was in people with mood disorders (50\%), with suicides in psychotic disorders showing a gender difference (females: 35.1\%; males: 19.8\%). Most significantly, the study showed that a psychiatric diagnosis had an adjusted odds ratio of 28.67 for risk of suicide.

The concept that psychiatric disorders significantly increase the risk of suicide is highlighted by a systematic literature review which showed that, of all factors studied, psychiatric disorders had the strongest association with suicide (all psychiatric disorders 91\%; of which mood disorders accounted for $55 \%$ and co-morbid diagnoses 44\%) [4]. A recent meta-analysis, which used data 
from both case-control studies and cohort studies, reported that the relative risk of suicide that could be attributed to any psychiatric disorder was $7.5 \%$ for males and $11.7 \%$ for females [5]. Together, these data demonstrate that there is an urgent need to understand the drives to suicidal tendencies in people with psychiatric illnesses; the ultimate goals of such investigations being to identify markers for such tendencies and/or to develop interventions to reduce this behaviour.

There is now a body of literature which supports the hypothesis that neurochemical changes in the brain are associated with suicidal behaviour, which include roles for the central serotonergic system [6], the signal transducer protein kinase $C$ [7] and the glutamatergic system [8]. There are also studies linking the endogenous opioidergic system to the major psychiatric disorders $[9,10]$ and suicide [11]. In the case of the mu opioid receptor (OPRM), it has been reported that these receptors are increased in the inferior frontal, cingulate, postcentral, medial temporal and lateral occipitotemporal gyri as well as the thalamus [12] of young $(<41$ years) people who had died as a result of suicide. OPRM were also reported to be increased in the frontal cortex and caudate [13] from people who had died as a result of suicide compared to those from age and sex matched control subjects. Significantly, one of these studies [12] only included people with depression among those who had died by suicide, whilst the second study predominantly consisted of people with undetermined diagnoses or depression (one subject had schizophrenia) [13]. Thus, it is not clear if there is an interaction between psychiatric disorder and OPRM in people who died by suicide. Finally, in a study that did not assign psychiatric diagnoses to the cohorts, it has been reported that OPRM in the prefrontal cortex from people who died by suicide bound agonists with a higher affinity than that for people who did not die by suicide. However, a decreased binding affinity was reported for the pre- and post-central gyri from people who died as a result of suicide [14].

Given the potential for changes in OPRM to be important in the predisposition of an individual to attempt suicide and the relative paucity of studies on OPRM, we decided to measure the density of OPRM using $\left[{ }^{3} \mathrm{H}\right]\left[\mathrm{D}-\mathrm{Ala}^{2}, \mathrm{~N}\right.$ $\mathrm{MePhe}^{4}$, Gly-ol]-enkephalin (DAMGO) binding in BA24 from people with no history of psychiatric disorders (controls), people who had died by suicide and had no discernable history of psychiatric disorders (suicides) and people with schizophrenia, major depressive disorder (MDD) or bipolar disorder (BP); some of whom had died by suicide.

Following our initial studies we went on to measure $\left[{ }^{3} \mathrm{H}\right] \mathrm{DAMGO}$ binding in BA 9 and the caudate-putamen $(\mathrm{CPu})$ from people with schizophrenia who had or had not died as a result of suicide and compared these data to those from age/sex matched controls (non-suicides) to begin to determine the extent of altered OPRM binding in these people. Finally, to determine if changes in radioligand binding were associated with changes in levels of OPRM protein, we used Western blotting and an antihuman OPRM antibody to measure protein levels in BA9, 24 and the caudate from the schizophrenia study cohorts.

\section{Methods}

Approval for this study was obtained from the Ethics Committee of the Victorian Institute of Forensic Medicine and the Mental Health Research and Ethics Committee of Melbourne Health (MHREC 2001.613). In all cases, tissue was obtained, post-mortem, after receiving written consent from the closest identifiable next-of kin. In compliance with State laws of the day, the source of the tissue collected up to 1999 was de-identified on completion of the case history review, tissue collected after 2002 was not de-identified. Tissues were provided by the Victorian Brain Bank Network as coded samples so that investigators cannot identify the donor.

\section{Diagnostic evaluation}

Case history reviews were conducted using the Diagnostic Instrument for Brain Studies (DIBS) $[15,16]$, with a psychologist and psychiatrist reaching a diagnostic consensus using DSM-IV criteria [17]. The inter-rater reliability of this instrument is $94 \%$ (mean kappa $=0.88$; $95 \%$ confidence interval $=0.7-1.0)[18]$. Following the review, duration of illness (DOI: time from first contact with psychiatric services to death) was calculated and latest prescribed doses of psychoactive drugs converted to standardised drug doses [19] (Additional file 1: Table S1). Importantly, CNS tissue was collected from cadavers refrigerated within 5 hours of being found, this has been shown to markedly slow autolysis processes and protein degradation [20]. The average time from discovery to autopsy was approximately 36 hours. To ensure preservation of the CNS molecular cytoarchitecture, samples were processed using a standardised procedure and rapidly frozen to $-70^{\circ} \mathrm{C}$ after removal at autopsy [21]. In cases where death was witnessed, the post-mortem interval (PMI) was the time between death and autopsy. Where death was not witnessed, PMI was calculated as the interval mid-way between the donor last being seen alive and being found dead. Central $\mathrm{pH}$ was determined as described previously [22]; this being recognised as a good indicator of tissue and protein preservation [23].

\section{Cohort selection and tissue processing}

Blocks of BA24 (ventral anterior cingulate gyrus, around the genu of the corpus callosum) were removed from the brains of 51 controls, 38 people with a diagnosis of schizophrenia (12 suicides), 20 people with a diagnosis of 
MDD (15 suicides), 13 people with a diagnosis of BP (5 suicides) and 9 suicides with no discernible history of a psychiatric disorder (see Table 1 for cohort summary and Additional file 1: Table S1 for details).

Blocks of BA9 (lateral surface of the frontal lobe, including the middle frontal gyrus superior to the inferior frontal sulcus) and the $\mathrm{CPu}$ were excised from the brains of the 36 people (11 suicides) with schizophrenia (tissue unavailable from 2 people) and 20 control age and sex subjects.

The radioligand binding assays were conducted as single point saturation studies [24], which gives a good estimate of total available binding sites. Importantly, the concentration of radioligand used was sufficiently high to overcome the minor changes in radioligand binding affinity that occurs in human CNS tissue [25] ensuring this approach gives a good estimation of total binding sites within the tissue [26]. Thus, $5 \mathrm{x} 20 \mu \mathrm{m}$ sections (3 total binding; TB, 2 non-specific binding; NS) were cut from each tissue block using a cryomicrotome (CM1800, Leica Microsystems) and thaw mounted onto gelatinised microscope slides. Approximately $100 \mathrm{mg}$ of gray matter for use in Western blots was excised from the slices these sections were taken from and stored at $-80^{\circ} \mathrm{C}$.

\section{Radioligand binding}

$\left[{ }^{3} \mathrm{H}\right]$ DAMGO binding $\left(3.3 \times 10^{-9} \mathrm{M}\right)$ was measured in the presence (NS) and absence (TB) of $10^{-6} \mathrm{M}$ naloxone; adapted from previous studies [12,27]. Sections were incubated in $50 \times 10^{-3} \mathrm{M}$ Tris- $\mathrm{HCl}$, pH7.4, for 1 hour. After incubation, sections were washed in ice-cold assay buffer, dipped in ice-cold water and thoroughly dried prior to being desiccated overnight in paraformaldehyde fumes. The sections, alongside $\left[{ }^{3} \mathrm{H}\right]$ micro-scales ${ }^{\mathrm{Tm}}$, were apposed to BAS-TR2025 imaging plates (14 days), which were scanned using a BAS5000 high resolution phosphoimager. The phosphoimage intensities were measured by comparison to the intensity of segments on

Table 1 A summary of the demographic and collection data (mean \pm SEM) for the cohort used in the determination of markers for mu opioid receptors

\begin{tabular}{lllll}
\hline Group & $\begin{array}{l}\text { Sample } \\
\text { size }\end{array}$ & $\begin{array}{l}\text { Age } \\
\text { (years) }\end{array}$ & $\begin{array}{l}\text { PMI } \\
\text { (hours) }\end{array}$ & Brain pH \\
\hline Controls & 51 & $52.90 \pm 2.62$ & $43.73 \pm 2.34$ & $6.280 \pm 0.036$ \\
\hline Suicides & 9 & $44.56 \pm 5.93$ & $33.69 \pm 3.67$ & $6.427 \pm 0.066$ \\
\hline MDD & 5 & $65.00 \pm 8.79$ & $34.70 \pm 4.34$ & $6.266 \pm 0.103$ \\
\hline MDD (suicide) & 15 & $50.93 \pm 4.69$ & $39.45 \pm 3.69$ & $6.572 \pm 0.053$ \\
\hline BP & 8 & $67.25 \pm 2.827$ & $36.03 \pm 6.688$ & $6.269 \pm 0.072$ \\
\hline BP (suicide) & 5 & $41.40 \pm 4.214$ & $32.10 \pm 4.173$ & $6.348 \pm 0.074$ \\
\hline Schizophrenia & 26 & $54.38 \pm 2.619$ & $38.07 \pm 2.395$ & $6.190 \pm 0.052$ \\
\hline Schizophrenia & 12 & $29.25 \pm 2.769$ & $44.67 \pm 4.030$ & $6.261 \pm 0.043$ \\
(suicide) & & & & \\
\hline
\end{tabular}

$\left[{ }^{3} \mathrm{H}\right]$ microscales $^{\mathrm{Tm}}$ using AIS image analysis software. Results were expressed as specific binding (TB minus NS) in dpm/mg estimated wet weight tissue equivalents (ETE) and converted to fmol/mg ETE [26].

\section{Western blots}

Homogenates were prepared from CNS tissue, at 5\% w/v, in $10 \times 10^{-3} \mathrm{M}$ Tris, $(\mathrm{pH} 7.4)$, containing $1 \%$ sodium dodecylsulphate and $1 \times 10^{-3} \mathrm{M}$ fresh sodium orthovanadate and diluted in reducing buffer to give final protein concentrations of $1.0 \mathrm{mg} / \mathrm{ml}$. Optimisation experiments showed that different protein concentrations from each region were within the linear range of the detection system. Thus the total protein loaded was; BA 9: $30 \mu \mathrm{g}$, BA 24: $10 \mu \mathrm{g}$ and caudate: $40 \mu \mathrm{g}$. The proteins in each sample (run in duplicate) were separated using polyacrylamide gel electrophoresis (4\% stacking gel, 10\% running gel). They were transferred to nitrocellulose membranes overnight in Towbin transfer buffer [28]. Equal protein loading and transfer was confirmed by staining with $0.1 \%$ ponceau $S$ in 3\% trichloroacetic acid. Membranes were blocked for an hour at room temperature in Tris buffered saline with 1\% Tween 20 (TTBS) and incubated with rabbit anti-OPRM antibody (1/2000 in TTBS) overnight at $4^{\circ} \mathrm{C}$. This was followed by incubation with goat antirabbit antibody conjugated to horseradish peroxidise (1/2000 in TTBS) for an hour at room temperature. The antigenic reaction was visualised using enhanced chemiluminescence (ECL) and imaged using a Kodak Image Station 440CF. The sum intensity of the antigenic bands was measured using Kodak 1D software.

To control for inter-blot variability, an internal control (IC) sample [29], was run (in duplicate) on every gel, which were imaged so that the sum intensity of the IC fell within a previously established range. The sum intensities of all samples were standardised as a ratio of Internal Control (ratio IC).

\section{Statistics}

All data sets were analysed using the D'Agostino \& Pearson omnibus normality test to determine whether they approximated to Gaussian distribution. If the data was normally distributed, a Grubb's test was used to determine the presence of outliers. Due to small sample sizes, age, PMI and brain $\mathrm{pH}$ for the groups were compared using a Kruskal-Wallis test with Dunn's Multiple Comparison Test. Pearson product-moment correlations, assuming a straight line fit, were used to determine if there was a relationship between these factors and experimental data. Interpretation of Pearson product-moment correlations was assisted by published guidelines [30]; with an $r$ value of $0.3\left(r^{2}=0.09\right)$ deemed to describe a typical relationship and a value of $0.5\left(\mathrm{r}^{2}=0.25\right)$ describing a substantial relationship. 
Where an association was found, the impact of the factors on the experimental data was determined by analysis of covariance (ANCOVA). For the radioligand binding data, a Student's unpaired $t$-test was used to determine whether there were changes in binding density with suicide. Due to the small samples sizes for some groups, a Kruskal-Wallis test with Dunn's Multiple Comparison Test, or a general linear model (GLM) which is most suitable for dealing with complex data sets were employed to identify variations in binding density between groups. Finally, in the schizophrenia/control cohort, one-way ANOVAs with Bonferroni's Multiple Comparison Test were used to identify variations in $\left[{ }^{3} \mathrm{H}\right]$ DAMGO binding and OPRM protein levels between groups in each CNS region. GLMs and ANCOVAs were conducted using Minitab (Release 13.31, www.minitab. com); all other statistical analyses were carried out using Graphpad Prism (version 5.04 for Windows, Graphpad Software, San Diego, California, USA).

\section{Results}

\section{Demographic and tissue collection data}

The final recorded antipsychotic dose (chlorpromazine equivalents) and duration of illness in the people with schizophrenia were the only collection-related variables not normally distributed. There were significant variances associated with age (Kruskal-Wallis statistic $=30.80$, $\mathrm{p}<0.0001$ ) and $\mathrm{pH} \quad$ (Kruskal-Wallis statistic $=27.87$, $\mathrm{p}<0.001$ ), but not PMI (Kruskal-Wallis statistic $=9.24$, $\mathrm{p}=0.24$ ) between the groups. Post-hoc Dunns Multiple Comparison test revealed that the variance with age was due to the schizophrenia _ suicide group being younger than the control $(\mathrm{p}<0.01)$, MDD_non_suicide $(\mathrm{p}<0.05)$, BP_non_suicide $(\mathrm{p}<0.001)$ and the schizophrenia_non_suicide groups $(\mathrm{p}<0.01$; Additional file 2 : Table S2). Using the same approach, the variance with brain $\mathrm{pH}$ was found to be due to the tissue from the MDD_suicide group being higher than for the control $(\mathrm{p}<0.01)$ and schizophrenia_suicide $(\mathrm{p}<0.01)$ and schizophrenia_non_suicide $(\mathrm{p}<0.001)$ groups (Additional file 2: Table S2).

\section{$\left[{ }^{3}\right.$ H]DAMGO Binding in BA24 and suicide}

$\left[{ }^{3} \mathrm{H}\right]$ DAMGO binding was homogenous across BA24 (see Figure 1a) therefore an integrated measure was taken across all cortical laminae. $\left[{ }^{3} \mathrm{H}\right]$ DAMGO binding from people who had or had not died from suicide approximated to a Gaussian distribution and a Grubbs test revealed no outlying data. Significantly, there was a $16 \%$ decrease in the density of radioligand binding to OPRM in BA24 from people who had died by suicide ( $\mathrm{n}=41$ ) compared to those who had not died by suicide $(\mathrm{n}=81, \mathrm{p}=0.008$, see Table 2 and Figure $1 \mathrm{~b})$.

\section{${ }^{3}$ H]DAMGO Binding in BA24, suicide and psychiatric diagnoses}

To determine if the changes in OPRM in BA24 showed any suicide $\mathrm{x}$ psychiatric diagnosis, we divided the data according to suicide status within each clinical diagnoses. This showed changes in $\left[{ }^{3} \mathrm{H}\right]$ DAMGO binding varied with suicide status $\left(\mathrm{F}_{7,114}=4.16, \mathrm{p}=0.0004\right)$ and was due to a $34 \%$ increase in binding in the BP_non_suicide group and a $33 \%$ decrease in the schizophrenia _ suicide group (see Table 2 and Figure 1c).

\section{Potential confounds}

There were substantial correlations between $\left[{ }^{3} \mathrm{H}\right]$ DAMGO binding and age in controls, MDD_non_suicide, MDD_suicide, BP_non_suicide and schizophrenia_suicide as well as between binding and $\mathrm{pH}$ in MDD and BP_suicide (Additional file 2: Table S2). Furthermore, when $\left[{ }^{3} \mathrm{H}\right]$ DAMGO binding was analysed with age and $\mathrm{pH}$ as cofactors, age $\left(\mathrm{F}_{1,89}=23.12, \mathrm{p}<0.0001\right)$ and $\mathrm{pH}$ $\left(\mathrm{F}_{1,89}=3.91, \mathrm{p}=0.05\right)$ were shown to contribute to the variance associated with the binding data. However, even taking these factors into account, the suicide $\mathrm{x}$ psychiatric diagnoses differences were still strongly significant $\left(\mathrm{F}_{7,89}=2.93, \mathrm{p}=0.008\right)$.

\section{Mu opioid receptors and suicide in schizophrenia $\left[{ }^{3}\right.$ H]DAMGO binding}

Whilst the primary focus of this study was the potential interactions between diagnoses $\mathrm{x}$ suicide, a sub-analyses of the BA 24 data revealed that there was a 33\% decrease in binding in the schizophrenia_suicide group compared to the schizophrenia_non_suicide group (Table 2), prompting further study of the potential interactions between suicide $\mathrm{x}$ schizophrenia in other CNS regions. Subsequently, we measured $\left[{ }^{3} \mathrm{H}\right] \mathrm{DAMGO}$ binding in BA9 (Figure 2a) and $\mathrm{CPu}$ (Figure 2b) from people with schizophrenia_suicide, schizophrenia_non_suicide and age matched controls only. These data were shown to approximate to a Gaussian distribution in both regions and Grubbs test revealed one outlier in the data in the $\mathrm{CPu}$ from people with schizophrenia $(\mathrm{Z}>2.82)$. For transparency, analyses are presented with and without that outlier. With the outlier, there was a significant variation in $\left[{ }^{3} \mathrm{H}\right]$ DAMGO binding in the $\mathrm{CPu}$ with diagnoses (With outlier: $\mathrm{F}_{2,53}=3.90, \mathrm{p}=0.026$; without outlier: $\left.\mathrm{F}_{2,52}=4.66, \mathrm{p}=0.013\right)$. Binding in the schizophrenia _ suicide group was decreased by $36 \%$ compared to controls and $31 \%$ compared to schizophrenia_non_suicide (Table 2, Figure 2c).

$\left[{ }^{3} \mathrm{H}\right] \mathrm{DAMGO}$ binding also varied with diagnoses in BA9 $\left(\mathrm{F}_{2,55}=6.81, \mathrm{p}=0.0023\right)$, due to a $24 \%$ decrease in binding in the schizophrenia_suicide group compared to controls and 30\% compared to schizophrenia_non_suicide (Table 2, 
a

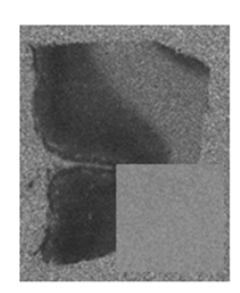

b

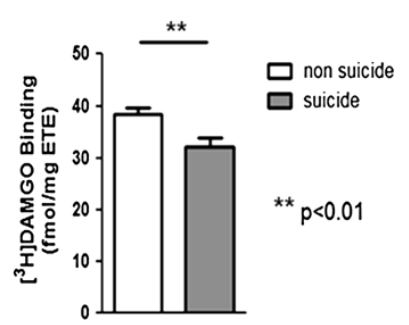

C

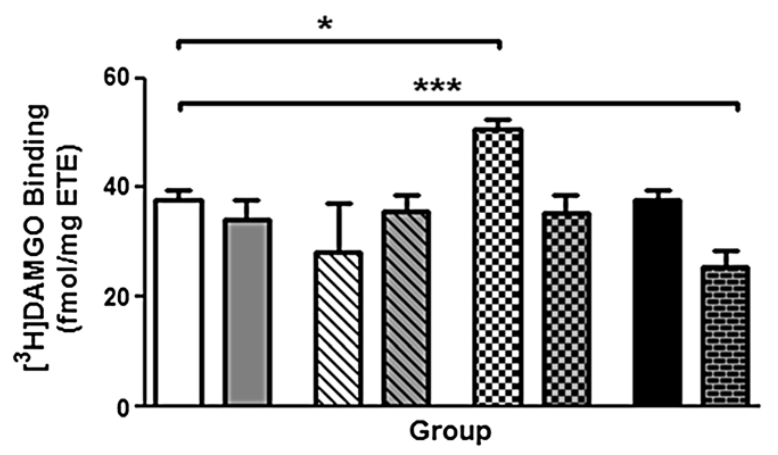

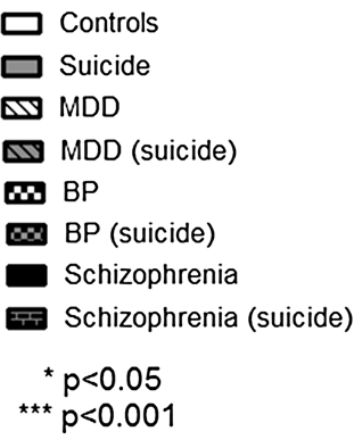

Figure 1 a) Representative autoradiograph of total $\left[{ }^{3} \mathrm{H}\right] \mathrm{DAMGO}$ binding in BA24. Insert shows non-specific binding. Results for the radioligand are represented graphically (mean $\pm \mathrm{SEM}$, fmole/mg ETE): b) Effect of suicide per se on levels of $\left.{ }^{3} \mathrm{H}\right] \mathrm{DAMGO}$ binding in BA24. $\mathbf{c}$ ) Effect of psychiatric disorder and suicide on levels of $\left.{ }^{3} \mathrm{H}\right] \mathrm{DAMGO}$ binding in BA24.

Figure 2c). In neither region did $\left[{ }^{3} \mathrm{H}\right]$ DAMGO binding in the schizophrenia_non_suicide differ from that in controls.

\section{Potential confounds}

Pearson product-moment correlations indicated that age, $\mathrm{pH}$ and DOI but not PMI or chlorpromazine equivalents, had significant associations with $\left[{ }^{3} \mathrm{H}\right]$ DAMGO binding (Additional file 2: Table S2). Significantly, reanalysing the schizophrenia cohort data with age and $\mathrm{pH}$ as covariates showed that although age $\left(\mathrm{F}_{1,161}=25.48, \mathrm{p}<0.0001\right)$ and $\mathrm{pH}\left(\mathrm{F}_{1,161}=5.64, \mathrm{p}=0.019\right)$ contributed to the variance in binding, the variation associated with suicide was still significant $\left(F_{2,161}=3.33\right.$, $\mathrm{p}=0.038$.

\section{OPRM protein}

The antigenic band measured in these studies had the predicted molecular weight for MOR and, in our hands, showed the expected rank order of intensity (reflecting OPRM levels) across different brain regions (i.e. thalamus > cortex > caudate; data not shown) [12,27]) and was present in thalamic membrane and cytosolic [31-33] but not nuclear fractions (Figure 3a).

OPRM data showed a Gaussian distribution with no outliers. There was no variance in OPRM protein levels between diagnostic groups in any region (BA9: $\mathrm{F}_{2,55}=0.644, \mathrm{p}=0.53$; BA24: $\mathrm{F}_{2,55}=0.953, \mathrm{p}=0.392$; caudate: $F_{2,53}=1.22, p=0.303$; see Figure $3 b$ ).
Overall, there were no correlations between age, $\mathrm{pH}$, DOI or chlorpromazine equivalents and OPRM levels (Additional file 2: Table S2). However, there were substantive relationships between OPRM level and age $\left(\mathrm{r}^{2}=0.4809\right)$ and $\mathrm{pH}\left(\mathrm{r}^{2}=0.3758\right)$ in BA9 from the schizophrenia_ suicide group. An ANCOVA revealed that neither age $\left(\mathrm{F}_{1,53}=0.67, \mathrm{p}=0.417\right)$ nor $\mathrm{pH}$ $\left(\mathrm{F}_{1,53}=2.12, \mathrm{p}=0.151\right)$ had a significant effect on OPRM levels in BA 9. Furthermore, taking these 2 factors into account did not affect the outcome of the analysis $\left(\mathrm{F}_{2,53}=0.72, \mathrm{p}=0.49\right)$.

\section{Discussion}

This study has shown decreased $\left[{ }^{3} \mathrm{H}\right]$ DAMGO binding in BA24, BA9 and the $\mathrm{CPu}$ from people with schizophrenia who died by suicide which, in BA24, was first revealed as a significant decrease in $\left[{ }^{3} \mathrm{H}\right]$ DAMGO binding in larger cohort where people who had died by suicide were compared to those who had not. Significantly there were no differences in $\left[{ }^{3} \mathrm{H}\right]$ DAMGO binding in BA 24 from people with either MDD or BP who had died as a result of suicide, making this a specific association with suicide in schizophrenia. However, this study did show an increase in $\left[{ }^{3} \mathrm{H}\right]$ DAMGO binding in BA24 from people with BP who did not died by suicide. Some caution is needed in the interpretation of this finding in BP because of the relatively small number of individuals making up this cohort, particularly given that lithium treatment has been shown to increase OPRM expression 
Table 2 Levels of [3 H]DAMGO (mean \pm SEM) binding in subjects with schizophrenia, major depressive disorder, bipolar disorder or no history of psychiatric disorder who did or did not die as a result of suicide

\begin{tabular}{|c|c|c|c|c|}
\hline Group BA 24 & $\begin{array}{l}\text { Sample } \\
\text { size }\end{array}$ & $\begin{array}{l}\text { [3 H]DAMGO binding } \\
\text { (fmole/mg ETE) }\end{array}$ & Analysis parameters & $P$ value \\
\hline Suicide & 41 & $32.25 \pm 1.76$ & $\mathrm{t}=2.7, \mathrm{df}=120$ (non-suicide) & 0.008 \\
\hline Non-suicide & 81 & $38.34 \pm 1.34$ & & \\
\hline Diagnosis/suicide & BA 24 & & & \\
\hline Controls & 51 & $37.63 \pm 1.83$ & & \\
\hline Suicides & 9 & $34.02 \pm 3.80$ & $\mathrm{t}=0.88$ (controls) & n.s \\
\hline MDD & 5 & $27.95 \pm 9.06$ & $\mathrm{t}=1.84$ (controls) & n.s \\
\hline MDD (suicide) & 15 & $35.69 \pm 2.84$ & $\mathrm{t}=0.58$ (controls) & n.s \\
\hline $\mathrm{BP}$ & 8 & $50.51 \pm 1.98$ & $\mathrm{t}=3.00$ (controls) & n.s \\
\hline BP (suicide) & 5 & $35.38 \pm 3.07$ & $\mathrm{t}=0.43$ (controls) & n.s \\
\hline Schizophrenia & 26 & $37.80 \pm 1.83$ & $\mathrm{t}=0.04$ (controls) & n.s \\
\hline Schizophrenia (suicide) & 12 & $25.31 \pm 3.17$ & $\mathrm{t}=3.39$ (controls) $\mathrm{t}=3.21$ (schizophrenia) & $<0.05$ \\
\hline Schizophrenia/suicide & BA 9 & & & \\
\hline Controls & 20 & $31.65 \pm 2.11$ & & \\
\hline Schizophrenia & 26 & $34.40 \pm 1.32$ & $\mathrm{t}=1.15$ (controls) & n.s \\
\hline \multirow[t]{2}{*}{ Schizophrenia (suicide) } & 12 & $24.12 \pm 2.27$ & $\mathrm{t}=2.57$ (controls) $\mathrm{t}=3.68$ (schizophrenia) & $<0.05<0.05$ \\
\hline & $\mathrm{CPu}$ & & & \\
\hline Controls & 20 & $25.40 \pm 2.16$ & & \\
\hline Schizophrenia & 24 & $23.72 \pm 1.37$ & $\mathrm{t}=0.67$ (controls) & n.s \\
\hline Schizophrenia (suicide) & 11 & $16.29 \pm 2.42$ & $\mathrm{t}=2.97$ (controls) $\mathrm{t}=2.50$ (schizophrenia) & $<0.05<0.05$ \\
\hline
\end{tabular}

The group comparison the analysis factors refer to is given in brackets below the parameters. Abbreviations: $n . s .=$ not significant.

in rats [34]. Although this novel finding deserves further investigation, it was not pursued in this study as it was not central to investigating the interactions between suicide $\mathrm{x}$ psychiatric disease.

Our study showed that $\left[{ }^{3} \mathrm{H}\right]$ DAMGO binding increased with age, replicating previous studies that have reported this relationship [12,13]. Significantly, although DAMGO binds to all OPRM splice variants with similar affinities [35] our data showed that levels of OPRM protein did not vary with age. Thus, our data is the first to indicate that the number of available $\left[{ }^{3} \mathrm{H}\right]$ DAMGO binding sites increases with age in the absence of changes in levels of OPRM, which would be consistent with decreasing levels of endogenous ligand occupancy with age. This hypothesis is supported from previous data on endogenous opioids in rat CNS [36] and in pain responsiveness in humans [37]. Together, these data suggest levels of endogenous opioid ligands decrease with age.

We have shown that decreased $\left[{ }^{3} \mathrm{H}\right] \mathrm{DAMGO}$ binding is detectable across several CNS regions in people with schizophrenia who died as a result of suicide, even when the effects of confounding factors such as age and tissue $\mathrm{pH}$ are taken into account, with no difference in binding levels between controls and people with schizophrenia. Our data partly replicates a previous study that showed no changes in binding to OPRM in people with schizophrenia who "had died from..... natural causes"
[38] but contrasts with another report showing decreased binding to OPRM in the caudate from people with the disorder [39]. The latter study used tissue from people who had died as a result of either suicide or pneumonia but did not explore whether there was an association between low levels of binding and suicide; thus, it is possible that the decrease reported was due to suicide. However, our finding of low $\left[{ }^{3} \mathrm{H}\right] \mathrm{DAMGO}$ binding density in suicide per se does not agree with previous studies which report increased OPRM binding in the inferior frontal, cingulate, postcentral, medial temporal and lateral occiptotemporal gyri as well as the thalamus of young suicides [12] and in the frontal cortex and caudate [13] from people who had died by suicide or unaltered levels of radioligand binding in prefrontal cortex and prepost central gyri from people who suicided [14]. Notably, in the earliest studies investigating suicide and OPRM, tissue was obtained from individuals who had died by suicide and predominantly had MDD or BP; thus, these data are in contrast with our findings of no difference in levels of OPRM binding in people with MDD or BP who had died by suicide. By contrast, our finding of no change in $\left[{ }^{3} \mathrm{H}\right]$ DAMGO binding in people with mood disorders or no history of psychiatric illness who had died by suicide is consistent with a previous study [14], which did not report on psychiatric diagnoses. 
a

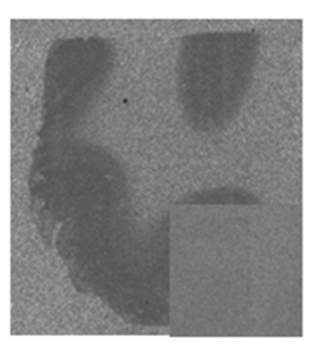

b

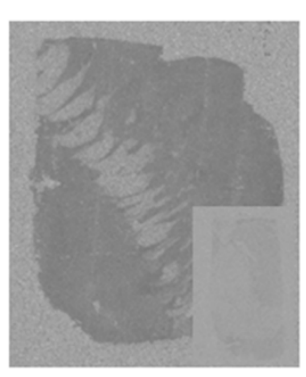

C

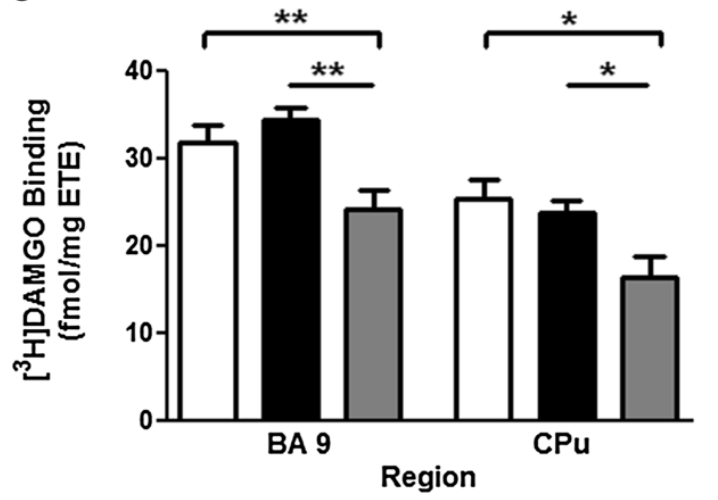

$\square$ Control

Schizophrenia (non-suicide)

$\square$ Schizophrenia (suicide)

${ }^{*} p<0.05$

${ }^{* *} p<0.01$

Figure 2 Representative autoradiographs of total [ ${ }^{3}$ H]DAMGO binding in a) BA9 and b) caudate-putamen; inserts show non-specific binding. c) Effect of suicide on radioligand binding in these areas are represented graphically (mean $\pm \mathrm{SEM}$, fmole/mg ETE).

As stated earlier, our findings of decreased $\left[{ }^{3} \mathrm{H}\right] \mathrm{DAMGO}$ binding with no changes in OPRM protein would be consistent with a change in receptor availability rather than receptor number. There are three scenarios that would account for this decrease in agonist binding without a change in overall levels of protein. Firstly, it is possible that there is a change in the confirmation of the receptor which affects the binding of the ligand. Secondly, the biochemical modifications that are required for the insertion of the receptor into the membrane could be aberrant, reducing the availability of the receptor but not affecting the overall number of receptors. Finally, the simplest explanation is that the decrease in binding is due to competition for the binding site between the radioligand and an endogenous ligand. The latter hypothesis has been argued previously in the report of altered affinity for $\left[{ }^{3} \mathrm{H}\right]$ DAMGO in tissue from people who died as a result of suicide [14] as changes in binding affinities are usually due to competition from endogenous ligands $[40,41]$. More recently, a positron emission tomography (PET) study reported that people with high impulsivity scores released higher levels of endogenous opioids in response to stress [42], resulting in lower $\left[{ }^{11} \mathrm{C}\right]$ carfentanil non-displacable binding potential. Impulsivity has been proposed as a candidate endophenotype for suicidal behaviour [43]; thus, it is possible the decreased OPRM availability in people with schizophrenia who died by suicide is due to increased endogenous opioid levels in response to external stressors. Two such molecules, endomorphin 1 and endomorphin 2, have high affinities and selectivity for OPRM (see [44]) making them prime candidates for future studies.

As with most approaches to the study of the neurobiology of psychiatric disorders, this study has some potentially confounding factors. In particular, we and others [12,13] have shown that $\left[{ }^{3} \mathrm{H}\right]$ DAMGO binding increases with age. In our study the changes in $\left[{ }^{3} \mathrm{H}\right]$ DAMGO binding remained when the effect of age was taken into account using an ANCOVA. Another confound is that all people with psychiatric disorders received psychotropic drugs prior to death. Overall, the literature suggests that treatment of rodents with antipsychotics results in either a decrease in the levels of OPRM $[45,46]$ or no change [47] although clozapine, which none of the subjects with schizophrenia received (see Additional file 1: Table S1 for details), has been reported to cause decreases [48]. Evidence against the change in $\left[{ }^{3} \mathrm{H}\right]$ DAMGO binding in tissue from people with schizophrenia who died by suicide being related simply to the effects of antipsychotic drugs are i) people with schizophrenia who did or did not die by suicide had been treated with antipsychotic drugs, receiving similar levels of final recorded drug doses expressed as chlorpromazine equivalents (Mann Whitney $U=131.0$, medians: schizophrenia_non_suicide = 1216, schizophrenia_suicide $=1418$; ) and the difference in $\left[{ }^{3} \mathrm{H}\right]$ DAMGO binding is present in all regions between these groups, ii) some of the people with BP had received 
a

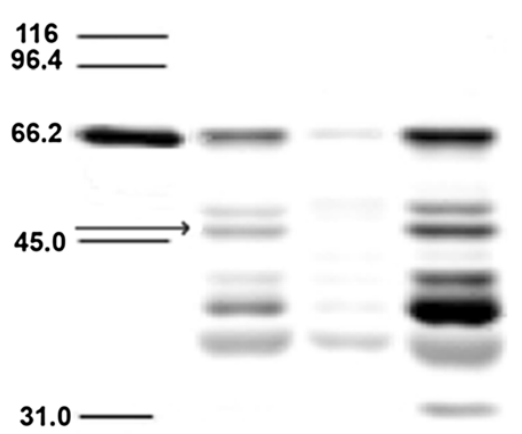

b

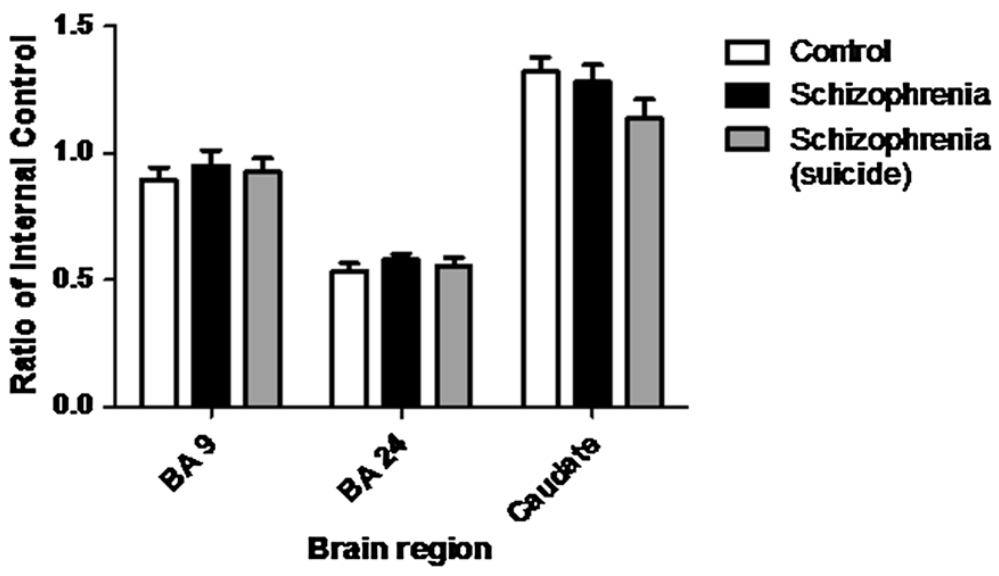

Figure 3 a) Western blot showing the levels of OPRM in (left to right): Molecular weight standards in lane 1, values given in kDa; membrane, nuclear and cytosol fractions, in lanes 2-4 respectively. Band measured in subsequent experiments identified by the arrow. b) Levels of OPRM protein in BA24, 9 and CPu from controls and people with schizophrenia who did or did not die as a result of suicide are represented graphically (mean $\pm \mathrm{SEM}$, ratio of internal control).

antipsychotic drugs before death but there was no change in $\left[{ }^{3} \mathrm{H}\right]$ DAMGO binding in people with this disorder who had died by suicide compared to control subjects and an increase in the BP_non_suicide group.

One potential methodological confound in our study was that the cohort size of people with schizophrenia who died as a result of suicide was relatively small. However, a power analysis (http://www.biomath.info/power/ ttest.htm) showed our study was appropriately powered in BA 9 and 24 (power level 0.8) but was underpowered for the mean differences observed in the $\mathrm{CPu}$ (9 additional non-suicide people were needed).

\section{Conclusions}

Our study is the first to suggest there is a decrease in the availability of $\left[{ }^{3} \mathrm{H}\right]$ DAMGO binding sites in people with schizophrenia who died by suicide. Given the strong link between schizophrenia and the inclination to complete suicide [49], further studies to understand the consequences of changes in the opioid system and its relationship to suicide in schizophrenia are warranted. It is possible that these chemical changes, if detectable by neuroimaging or by a peripheral measure, could be used clinically to identify people with a disposition to suicide which would facilitate the implementation of appropriate interventions [50]. Similarly, our novel, preliminary data on increased $\left[{ }^{3} \mathrm{H}\right]$ DAMGO binding in BP are intriguing and deserve further investigations. Both findings add to the long held argument that the opioid system plays an important role in the pathophysiology and/or outcomes of psychiatric disorders [51].

\section{Additional files}

Additional file 1: Table S1. Donor information related to the subjects from whom tissue was used for the measurement of markers for the mu opioid receptor. Description of data: Detailed information of the cohort from whom tissue was sourced for this study, includes demographic data.

Additional file 2: Table S2. Correlations between demographic and tissue collection data and measures of mu opioid receptors. Description of data: Detailed information of the relationships between potential confounding factors and the experimental measures assessed in this study. 


\section{Competing interests}

There are no competing financial interests in relation to the work described in this paper. TTM, GP \& JN report no competing interests. The following authors have received remuneration in the past: ES received honorarium from Astra-Zeneca and travel support from GSK. BD received travel support from GSK, honorarium from Pfizer, Eli Lilly and MSD.

\section{Authors' contributions}

ES was involved in the conceptualisation, design, supervision of research and analysis of the project and had the primary responsibility for drafting the manuscript. TTM undertook the radioligand binding and Western blots in the schizophrenia cohort and had input into the manuscript. GP and JN were responsible for the radioligand binding in the suicide cohort and had input into the manuscript. BD was involved in the conceptualisation, design and analysis of the project as well as having significant input into the manuscript. All authors read and approved the final manuscript.

\section{Acknowledgements}

This study was supported by an NHMRC project grant (\#509306) and Operational Infrastructure Support (OIS) from the Victorian State Government. Partial funding for the Kodak Image Station 440CF was provided by Equity Trustees. ES was the Royce Abbey Postdoctoral Fellow and TM was an lan Scott scholar, both funded by the Australian Rotary Health Research Fund. ES is now an ARC Future Fellow (FT100100689). BD is a NH\&MRC Senior Research Fellow (\#APP1002240). The Victorian Brain Bank Network is supported by the Mental Health Research Institute, The Alfred, Victorian Forensic Institute of Medicine, The University of Melbourne and funded by Australia's National Health \& Medical Research Council, Helen Macpherson Smith Trust, Parkinson's Victoria and Perpetual Philanthropic Services.

Received: 21 November 2011 Accepted: 23 August 2012

Published: 28 August 2012

\section{References}

1. Maris RW: Suicide. Lancet 2002, 360:319-326

2. Mortensen PB, Agerbo E, Erikson T, Qin P, Westergaard-Nielsen N: Psychiatric illness and risk factors for suicide in Denmark. Lancet 2000, 355:9-12.

3. Chen EY, Chan WS, Wong PW, Chan SS, Chan CL, Law YW, Beh PS, Chan KK, Cheng JW, Liu KY, et al: Suicide in Hong Kong: a case-control psychological autopsy study. Psychol Med 2006, 36:815-825.

4. Cavanagh JT, Carson AJ, Sharpe M, Lawrie SM: Psychological autopsy studies of suicide: a systematic review. Psychol Med 2003, 33:395-405.

5. Li Z, Page A, Martin G, Taylor R: Attributable risk of psychiatric and socio-economic factors for suicide from individual-level, population-based studies: a systematic review. Soc Sci Med 2011, 72:608-616.

6. Kamali M, Oquendo MA, Mann JJ: Understanding the neurobiology of suicidal behavior. Depress Anxiety 2001, 14:164-176.

7. Pandey GN, Dwivedi Y, Pandey SC, Conley RR, Roberts RC, Tamminga CA Protein kinase $C$ in the postmortem brain of teenage suicide victims. Neurosci Lett 1997, 228:111-114.

8. Nowak G, Ordway GA, Paul IA: Alterations in the N-methyl-asparatate (NMDA) receptor complex in the frontal cortex of suicide victims. Brain Res 1995, 675:157-164.

9. Kennedy SE, Koeppe RA, Young EA, Zubieta JK: Dysregulation of endogenous opioid emotion regulation circuitry in major depression in women. Arch Gen Psychiatry 2006, 63:1199-1208.

10. Peckys D, Hurd YL: Prodynorphin and kappa opioid receptor mRNA expression in the cingulate and prefrontal cortices of subjects diagnosed with schizophrenia or affective disorders. Brain Res Bull 2001, 55:619-624.

11. Sher $L$, Stanley $B H$ : The role of endogenous opioids in the pathophysiology of self-injurious and suicidal behavior. Arch Suicide Res 2008, 12:299-308.

12. Gross-Isseroff R, Dillon KA, Israeli M, Biegon A: Regionally selective increases in mu opioid receptor density in the brains of suicide victims. Brain Res 1990, 530:312-316.

13. Gabilondo AM, Meana JJ, Garcia-Sevilla JA: Increased density of mu-opioid receptors in the postmortem brain of suicide victims. Brain Res 1995, 682:245-250.
14. Zalsman G, Molcho A, Huang Y, Dwork A, Li S, Mann JJ: Postmortem $\mu$-opioid receptor binding in suicide victims and controls. J Neural Transm 2005, 112:949-954

15. Roberts SB, Hill CA, Dean B, Keks NA, Opeskin K, Copolov DL: Confirmation of the diagnosis of schizophrenia after death using DSM- IV: a victorian experience. Aust N Z J Psychiatry 1998, 32:73-76.

16. Hill C, Keks N, Roberts S, Opeskin K, Dean B, Copolov D: Diagnostic instrument for brain studies. Melbourne: Mental Health Research Institute; 1999

17. American Psychiatric Association: Diagnostic and statistical manual of mental disorders. Washington, D.C.: American Psychiatric Association; 1994.

18. Hill C, Keks N, Roberts S, Opeskin K, Dean B, MacKinnon A, Copolov D: Problem of diagnosis in postmortem brain studies of schizophrenia. Am J Psychiatry 1996, 153:533-537.

19. Remington GJ: Antipsychotics (Neuroleptics). In Clincal handbook of psychotropic drugs. 9th edition. Edited by Bezchlibnyk-Butler KZ, Jeffries JJ. Seattle; Toronto: Göttingen; Bern: Hogrefe \& Huber; 1999:55-84.

20. Ferrer I, Santpere G, Arzberger T, Bell J, Blanco R, Boluda S, Budka H, Carmona M, Giaccone G, Krebs B, et al: Brain protein preservation largely depends on the postmortem storage temperature: implications for study of proteins in human neurologic diseases and management of brain banks: a BrainNet Europe Study. J Neuropathol Exp Neurol 2007, 66:35-46.

21. Dean B, Pavey G, Chai SW, Mendelsohn FAO: The localisation and quantification of molecular changes in the human brain using in situ radioligand binding and autoradiography. In The use of CNS autopsy tissue in psychiatric research: a practical guide. Edited by Dean B, Hyde TM, Kleinman JE. Sydney: Gordon \& Breach Science Publishers; 1999:67-83.

22. Kingsbury AE, Foster OJ, Nisbet AP, Cairns N, Bray L, Eve DJ, Lees AJ, Marsden CD: Tissue $\mathrm{pH}$ as an indicator of mRNA preservation in human post-mortem brain. Brain Res Mol Brain Res 1995, 28:311-318.

23. Stan AD, Ghose S, Gao XM, Roberts RC, Lewis-Amezcua K, Hatanpaa KJ Tamminga CA: Human postmortem tissue: what quality markers matter? Brain Res 2006, 1123:1-11.

24. Rodbard D: Mathematics and statistics of ligand assays. In Ligand Assay: analysis of international developments on isotopic and nonisotopic immunoassay. 1st edition. Edited by Langan J, Clapp JJ. New York: Masson; 1981:55-101.

25. Dean B, Pavey G, Opeskin K: [3H]raclopride binding to brain tissue from subjects with schizophrenia: methodological aspects. Neuropharmacology 1997, 36:779-786.

26. Pavey GM, Copolov DL, Dean B: High-resolution phosphor imaging: validation for use with human brain tissue sections to determine the affinity and density of radioligand binding. J Neurosci Methods 2002, 116:157-163.

27. Gabilondo AM, Meana JJ, Barturen F, Sastre M, Garcia-Sevilla JA: mu-opioid receptor and alpha 2-adrenoceptor agonist binding sites in the postmortem brain of heroin addicts. Psychopharmacology (Berl) 1994, 115:135-140.

28. Towbin H, Staehelin T, Gordon J: Electrophoretic transfer of proteins from polyacrylamide gels to nitrocellulose sheets: procedure and some applications. Proc Natl Acad Sci USA 1979, 76:4350-4354.

29. Dean B, Gray L, Keriakous D, Scarr E: A comparison of M1 and M4 muscarinic receptors in the thalamus from control subjects and subjects with schizophrenia. Thalamus \& Related Systems 2004, 2:287-295.

30. Gliner JA, Morgan GA, Harmon RJ: Basic associated designs: analysis and interpretation. J Am Acad Child Adolesc Psychiatry 2002, 41:1256-1258.

31. Hassan AHS, Almeida OFX, Gramsch C, Herz A: Immunocytochemical demonstration of opioid receptors in selected rat brain areas and neuroblastoma + glioma hybrid (NG108-15) cells using a monoclonal anti-idiotypic antibody. Neuroscience 1989, 32:269-278.

32. Svingos AL, Colago EE, Pickel VM: Vesicular acetylcholine transporter in the rat nucleus accumbens shell: subcellular distribution and association with mu-opioid receptors. Synapse 2001, 40:184-192.

33. Phansuwan-Pujito $P$, Ebadi M, Govitrapong P: Immunocytochemical characterization of delta-opioid and mu-opioid receptor protein in the bovine pineal gland. Cells Tissues Organs 2006, 182:48-56.

34. de Gandarias JM, Acebes I, Echevarria E, Vegas L, Abecia LC, Casis L: Lithium alters mu-opioid receptor expression in the rat brain. Neurosci Lett 2000, 279:9-12. 
35. Pan L, Xu J, Yu R, Xu MM, Pan YX, Pasternak GW: Identification and characterization of six new alternatively spliced variants of the human [mu] opioid receptor gene, Oprm. Neuroscience 2005, 133:209-220.

36. Morley JE, Flood JF, Silver AJ: Opioid peptides and aging. Ann N Y Acad Sci 1990, 579:123-132.

37. Washington LL, Gibson SJ, Helme RD: Age-related differences in the endogenous analgesic response to repeated cold water immersion in human volunteers. Pain 2000, 89:89-96.

38. Owen F, Cross AJ, Crow TJ, Lofthouse R, Poulter M: Neurotransmitter receptors in brain in schizophrenia. Acta Psychiatr Scand Supp/ 1981, 291:20-28.

39. Reisine TD, Rossor M, Spokes E, Iversen LL, Yamamura HI: Opiate and neuroleptic receptor alterations in human schizophrenic brain tissue. Adv Biochem Psychopharmacol 1980, 21:443-450.

40. van der Werf JF, Sebens JB, Vaalburg W, Korf J: In vivo binding of $\mathrm{N}$-n-propylnorapomorphine in the rat brain: regional localization, quantification in striatum and lack of correlation with dopamine metabolism. Eur J Pharmacol 1983, 87:259-270.

41. Kohler C, Hall H, Ogren SO, Gawell L: Specific in vitro and in vivo binding of $3 \mathrm{H}$-raclopride. A potent substituted benzamide drug with high affinity for dopamine D-2 receptors in the rat brain. Biochem Pharmacol 1985, 34:2251-2259.

42. Love TM, Stohler CS, Zubieta JK: Positron emission tomography measures of endogenous opioid neurotransmission and impulsiveness traits in humans. Arch Gen Psychiatry 2009, 66:1124-1134

43. Mann JJ, Arango VA, Avenevoli S, Brent DA, Champagne FA, Clayton P, Currier D, Dougherty DM, Haghighi F, Hodge SE, et al: Candidate endophenotypes for genetic studies of suicidal behavior. Biol Psychiatry 2009, 65:556-563.

44. Fichna J, Janecka A, Costentin J, Do Rego JC: The Endomorphin System and Its Evolving Neurophysiological Role. Pharmacol Rev 2007, 59:88-123.

45. Bower CM, Hyde TM, Zaka M, Hamid EH, Baca SM, Egan MF: Decreased mu-opioid receptor binding in the globus pallidus of rats treated with chronic haloperidol. Psychopharmacology (Berl) 2000, 150:260-263.

46. Sasaki T, Kennedy JL, Nobrega JN: Autoradiographic mapping of mu opioid receptor changes in rat brain after long-term haloperidol treatment: relationship to the development of vacuous chewing movements. Psychopharmacology (Berl) 1996, 128:97-104

47. Delay-Goyet P, Zajac JM, Roques BP: Effects of repeated treatment with haloperidol on rat striatal neutral endopeptidase, and on mu- and delta-opioid binding sites: comparison with chronic morphine and chronic kelatorphan. Neurosci Lett 1989, 103:197-202.

48. Zhang SP, Connell TA, Price T, Simpson GM, Zhou LW, Weiss B: Continuous infusion of clozapine increases mu and delta opioid receptors and proenkephalin mRNA in mouse brain. Biol Psychiatry 1995, 37:496-503.

49. Palmer BA, Pankratz VS, Bostwick JM: The lifetime risk of suicide in schizophrenia: a reexamination. Arch Gen Psychiatry 2005, 62:247-253.

50. Pompili M, Girardi P, Ruberto A, Tatarelli R: Toward a new prevention of suicide in schizophrenia. World J Biol Psychiatry 2004, 5:201-210.

51. Welch EB, Thompson DF: Opiate antagonists for the treatment of schizophrenia. J Clin Pharm Ther 1994, 19:279-283.

\section{Submit your next manuscript to BioMed Central and take full advantage of:}

- Convenient online submission

- Thorough peer review

- No space constraints or color figure charges

- Immediate publication on acceptance

- Inclusion in PubMed, CAS, Scopus and Google Scholar

- Research which is freely available for redistribution

Submit your manuscript at www.biomedcentral.com/submit 